\title{
LESSON 91
}

MARGINS: Pica, 20-70; Elite, 30-80.

Warm up: alphabet sentence

\section{Improve Accuracy}

35 wpm 5 minutes.

A33 - SI 1.29

Test your Skill

5 minutes.

MARGINS: Pica, 10-72; Elite, $15-85$.

Keep the right margin as straight as possible.

Use double-line spacing.

T19 - SI 1.46
Type this sentence as many times as your teacher asks.

The garage man tried to persuade him to buy a Zephyr, but he was quite sure he wanted a Vauxhall and a Ford was not for Jack.

A cheque is an order in writing, addressed to a banker telling him to pay a certain sum of money from the account of a named person, to another. A great many cheques are written every day and a man or woman working on the counter in a bank must see that all details are filled in correctly before he or she makes any payment on the cheque.

Certain points must be observed before a bank will accept a cheque. First, the cheque must have a date on it that is not more than six months back at the time of presentation or for any future date yet to come. Secondly, it must state the name and address or branch of the bank. The person to whom the money is to be paid must be written in and the amount of money to be paid in writing and figures, must be indicated. Finally, the person wishing to make the payment must sign the cheque. If you had no cheque book, you could write it on any paper at hand.

The three kinds of production are extractive, manufacturing and constructive. Extractive is all about obtaining raw materials from the land, under the land or from the sea. Mining, fishing, timber hauling and farming are all examples of extractive industries.

These products of the land or sea, find their way to the manufacturing industries where they are the raw materials, to be used in the production of goods such as steel, which need iron ore, coal and limestone from the extractive industries before it can be produced.

The constructive industries take the products of the extractive and manufacturing industries and put them together to make the final products which will be used by people in general. The car makers take the various components made by a large number of firms and simply construct cars with them. The bricklayer will use bricks, manufactured by others as his raw material and construct buildings out of them. It is all part of the chain of Production.

(59)

(2)

(

(1)

6

(4)

6

7

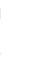

(

1

(1)

(1)

3

\begin{tabular}{|l|l|l|l|l|l|l|l|l|l|l|l|l|l|}
$\mid$ & 1 & 2 & 3 & 4 & 5 & 6 & 7 & 8 & 9 & 10
\end{tabular} \mid

